www.jmscr.igmpublication.org

Impact Factor 3.79

Index Copernicus Value: 5.88

ISSN (e)-2347-176x ISSN (p) 2455-0450

crossref DOI: _http://dx.doi.org/10.18535/jmscr/v4i02.73

\title{
Effect of Hibiscus sabdariffa extract Orally Administered on Lipid Parameters of Albino Rats
}

\author{
Authors \\ Ibioku Elekima*, Donatus Onwuli, Uchechukwu Achor Obisike, \\ Constancy Prisca Aleru, Serekara Gideon Christian, Josephine Osiagor \\ Department of Medical Laboratory Science, Rivers State University of Science and Technology, Port \\ Harcourt, Nigeria \\ Correspondent Author \\ Elekima, Ibioku \\ Department of Medical Laboratory Science, Rivers State University of Science and Technology, \\ PortHarcourt, Nigeria.Tel: +2347039469715 \\ Email:asaboasa@rocketmail.com
}

\begin{abstract}
Lipid parameters were investigated in albino rats of different groups after administration of $0.0 \mathrm{mg} / \mathrm{ml}$, $25.0 \mathrm{mg} / \mathrm{ml}, 50.0 \mathrm{mg} / \mathrm{ml}, 100.0 \mathrm{mg} / \mathrm{ml}$ and $200.0 \mathrm{mg} / \mathrm{ml}$ of aqueous extract of Hibiscus sabdariffa. The results obtained show that total cholesterol, triglyceride, high density lipoprotein cholesterol (HDL-C) and low density lipoprotein cholesterol $(L D L-C)$ levels of the control group were $112.70 \pm 1.84,103.80 \pm 1.22$, $26.14 \pm 1.71$ and $66.35 \pm 1.02$ respectively. The control results when compared to the study groups of $B, C, D$ and $E$ whose values were $89.75 \pm 1.97,82.26 \pm 2.79,73.65 \pm 2.19,64.39 \pm 1.58 ; 99.73 \pm 1.76,95.44 \pm 1.50,90.26 \pm$ $1.66,85.58 \pm 1.31 ; 27.38 \pm 1.19,30.25 \pm 2.11,33.35 \pm 1.03,35.34 \pm 1.70$, and $42.44 \pm 1.32,32.89 \pm 1.15,22.57 \pm 1.39$, $11.9 \pm 0.53$ respectively showed a significant decrease $(p \leq 0.05)$ for cholesterol, triglyceride and $L D L-$ cholesterol. However, HDL-cholesterol showed a significant increase $(P \leq 0.05)$ when compared with the control group. These findings implies that the administration of Hibiscus sabdariffaaqueous extract have protective effects against hyperlipidemia related disorders such as cardiovascular diseases.

Keywords: Hibiscus sabdariffacalyx (leaves);Total Cholesterol; Triglycerides; High Density Lipoprotein; Low Density Lipoprotein.
\end{abstract}

\section{Introduction}

Hibiscus sabdariffa belongs to the genus of Hibiscus of the family Malvaceae ${ }^{[1],[2]}$. The major part of the plant that is commonly consumed is the calyx ${ }^{[2],[3]}$. It appears bright red in colour and has a long history of use especially in tropical countries as non-alcoholic drink with sour taste due to its acidic nature ${ }^{[4],[5],[3],[6]}$. The plant Hibiscus sabdariffa has several medicinal properties [1], [3], [6]-[11] further reported in their respective studies that because of the presence of phytochemical constituents such as anthocyanins, protocatechmic acid and flavonoids such as petine, hibiscetine and sabdaretine contained in Hibiscus Sabdariffa, it play vital role in disease prevention, acting as antioxidant, antibacterial, as well as nephro and hepato protective functions. As stated by Allen and ${ }^{[12]}$; Overproduction of free radicals, reactive oxygen 
species and peroxides can induce cellular damage, leading to systemic derangements like inflammation, cardiovascular disorders and neoplasm. The extract also contains water, calcium, trace elements, riboflavin, $\beta$-carotene, Vitamin B, C, Protein and carbohydrate which are essential in wound healing, maintenance of blood vessels, good sight, nervous system and good metabolism ${ }^{[10],[13]}$. The fleshy red calyces are also used in making wine, juice, jelly, ice cream, cakes, spice and sauces ${ }^{[1]}$. Hibiscus sabdariffa is known by many common names especially in tropical countries such as dawadawa, Botso, Zobo, etc. ${ }^{[14],[15],[3]}$. "Zobo" is a common beverage consumed irrespective of age, sex, cultural and religious backgrounds in Nigeria. Several studies have shown the medicinal benefits of Hibiscus sabdariffa extract. However, since obesity and disorders of lipid metabolism are on the increase in developing countries such as Nigeria, the main focus of this study is to investigate the effect of Hisbiscus sabdariffa extract on lipid parameters such as total cholesterol (TCHOL), high density lipoprotein cholesterol (HDL-C),low density lipoprotein (LDL-C) and triglycerides (TG) using albino rats.

\section{Materials and Methods \\ Materials}

Materials used were albino rats (Ratus ratus) and Hibiscus sabdariffa (dried leaves) purchased from the University of Port Harcourt animal farm and Mile 1 Market, Port Harcourt, Nigeria respectively. Cholesterol, triglyceride and HDL Diagnostic reagents from Randox Laboratories Limited, U.K.

\section{Experimental Section}

\section{Preparation of Hibiscus sabdariffa Extract}

Dried leaves of Hibiscus sabdariffa were grounded and filtered through $1 \mathrm{~mm}$ sieve to obtain fine powder. Twenty-five grams of the fine powder was then dissolved in $250 \mathrm{ml}$ of distilled water. The entire content was boiled at $100^{\circ} \mathrm{C}$ for 10 minutes. The extract was allowed to cool, filtered and stored in capped transparent sterile bottles and kept in refrigerator before use.

\section{Animal Treatment}

Forty healthy male albino rats weighing approximately 200grams were used. The animals fed with commercial chicken growers mash and water for three weeks were randomly distributed into five groups with eight rats per group designated $\mathrm{A}, \mathrm{B}, \mathrm{C}, \mathrm{D}$, and $\mathrm{E}$.

\section{Treatment and Administration of Extract}

Group A(control) were treated with sterile normal saline. Rats in Group B, C, D and E were treated with $25 \mathrm{mg} / \mathrm{ml}, 50 \mathrm{mg} / \mathrm{ml}, 100 \mathrm{mg} / \mathrm{ml}$ and $200 \mathrm{mg} / \mathrm{ml}$ doses of the Hibiscus sabdariffa aqueous extract respectively. The method of administration was done by means of oral compulsion using oral can nula. This was performed daily for three weeks.

\section{Sample Collection}

At the end of the third week, twelve hours after administration of the last Hibiscus sabdariffa extract all the rats were sacrificed. Blood samples were collected by cardiac puncture into a plain bottles using sterile syringes and needles. Clotted samples were spun at $1200 \mathrm{rpm}$ for 5 minutes to obtain serum.

\section{Determination of Serum Lipid parameters}

Serum samples were used to estimate the following clinical chemistry parameters: Total cholesterol, Triglycerides, HDL-C and LDL-C using kits procured from Randox Laboratories, United Kingdom. The concentration of the lipid parameters were measured spectrophotometrically at $520 \mathrm{~nm}$.

\section{Statistical analysis}

Data obtained were analyzed using Graph pad Prism 5.0 software. Descriptive statistics in form of mean, standard deviation and inferential statistics using the unpaired statistical t-test was used to make comparison between the control group and the study groups. A $\mathrm{P}$ value of $\mathrm{P}<0.05$ was considered statistically significant. Obtained results were expressed as Mean \pm Standard deviation. 


\section{Results}

The results obtained from this study are shown in table 1, 2, 3, 4 and 5. The Mean \pm standard deviation of total cholesterol were $112.70 \pm 1.84$, $89.75 \pm 1.97, \quad 82.26 \pm 2.79, \quad 73.65 \pm 2.19, \quad$ and $64.39 \pm 1.58$ for the control (group A), Group B, C, $\mathrm{D}$ and $\mathrm{E}$ respectively. That of the triglyceride was $103.80 \pm 1.22,99.73 \pm 1.76,95.44 \pm 1.50,90.26 \pm$ 1.66, and 85.58 \pm 1.31 for control, group B, C, D and E respectively. For HDL-Cholesterol, the values were $26.14 \pm 1.71 \quad 27.38 \pm 1.19, \quad 30.25 \pm 2.11$,

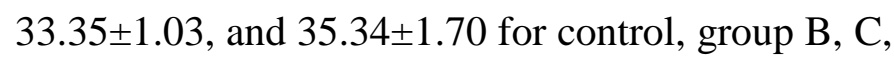
$\mathrm{D}$ and $\mathrm{E}$. and finally, that of LDL-Cholesterol were $66.35 \pm 1.02, \quad 42.44 \pm 1.32, \quad 32.89 \pm 1.15,22.57 \pm 1.39$ and 11.9 \pm 0.53 for control, group B, C, D and E respectively. As shown, total cholesterol levels decreases as the concentration of the dose increases across the groups. The same trend was observed in triglyceride and LDL-C values except in HDL-C where the levels increases as the concentration of the doses were increased (See table 1).

Table 1: Results obtained in the different groups

$\begin{array}{lllll}\text { Group } & \text { T.CHOL } & \text { T.G } & \text { HDL-C } & \text { LDL-C } \\ \text { Grp A }(\text { Ctrl }) & 112.70 \pm 1.84 & 103.80 \pm 1.22 & 26.14 \pm 1.71 & 66.35 \pm 1.02 \\ \text { Grp B } & 89.75 \pm 1.97 & 99.73 \pm 1.76 & 27.38 \pm 1.19 & 42.44 \pm 1.32 \\ \text { Grp C } & 82.26 \pm 2.79 & 95.44 \pm 1.50 & 30.25 \pm 2.11 & 32.89 \pm 1.15 \\ \text { Grp D } & 73.65 \pm 2.19 & 90.26 \pm 1.66 & 33.35 \pm 1.03 & 22.57 \pm 1.39 \\ \text { Grp E } & 64.39 \pm 1.58 & 85.58 \pm 1.31 & 35.34 \pm 2.70 & 11.94 \pm 0.53\end{array}$

Table 2: Comparison of group (Control and Group B)

$\begin{array}{lllll}\text { Group } & \text { T.CHOL } & \text { T.G } & \text { HDL-C } & \text { LDL-C } \\ \text { Grp A } & 112.70 \pm 1.84 & 103.80 \pm 1.22 & 26.14 \pm 1.71 & 66.35 \pm 1.02 \\ \text { Grp B } & 89.75 \pm 1.97 & 99.73 \pm 1.76 & 27.38 \pm 1.19 & 42.44 \pm 1.32 \\ \text { p value } & <0.0001 & <0.0001 & <0.1158 & <0.0001 \\ \text { p }<0.05 & \text { S } & \text { S } & \text { NS } & \text { S }\end{array}$

Table 3: Comparison of group (Control and Group C)

$\begin{array}{lllll}\text { Group } & \text { T.CHOL } & \text { T.G } & \text { HDL-C } & \text { LDL-C } \\ \text { Grp A } & 112.70 \pm 1.84 & 103.80 \pm 1.22 & 26.14 \pm 1.71 & 66.35 \pm 1.02 \\ \text { Grp C } & 82.26 \pm 2.79 & 95.44 \pm 1.50 & 30.25 \pm 2.11 & 32.89 \pm 1.15 \\ \text { p value } & <0.0001 & <0.0001 & <0.0008 & <0.0001 \\ \text { p }<0.05 & \mathrm{~S} & \mathrm{~S} & \mathrm{~S} & \mathrm{~S}\end{array}$

Table 4: Comparison of group (Control and Group D)

$\begin{array}{lllll}\text { Group } & \text { T.CHOL } & \text { T.G } & \text { HDL-C } & \text { LDL-C } \\ \text { Grp A } & 112.70 \pm 1.84 & 103.80 \pm 1.22 & 26.14 \pm 1.71 & 66.35 \pm 1.02 \\ \text { Grp D } & 73.65 \pm 2.19 & 90.26 \pm 1.66 & 33.35 \pm 1.03 & 22.57 \pm 1.39 \\ \text { p value } & <0.0001 & <0.0001 & <0.0001 & <0.0001 \\ \text { p }<0.05 & \text { S } & \text { S } & \text { S } & \text { S }\end{array}$

Table 5: Comparison of group (Control and Group E)

$\begin{array}{lllll}\text { Group } & \text { T.CHOL } & \text { T.G } & \text { HDL-C } & \text { LDL-C } \\ \text { Grp A } & 112.98 \pm 1.72 & 103.82 \pm 1.23 & 26.14 \pm 1.71 & 66.36 \pm 1.03 \\ \text { Grp E } & 64.39 \pm 1.58 & 85.58 \pm 1.31 & 35.34 \pm 2.70 & 11.94 \pm 0.53 \\ \text { pvalue } & <0.0001 & <0.0001 & <0.0001 & <0.0001 \\ \text { p }<0.05 & \mathrm{~S} & \mathrm{~S} & \mathrm{~S} & \mathrm{~S}\end{array}$

KEY: $\mathrm{S}=$ Significant, NS = Not Significant 


\section{Discussion}

During the administration of the extract, no deaths occurred in animals of any group. There were no abnormal signs ingroups. The results obtained showed a significant decrease $(\mathrm{P}<0.001)$ in triglyceride, total cholesterol and low density lipoprotein levels in the test groups when compared with the control group. The significant decrease seen in the test group maybe as a result of dietary antioxidants activity of anthocyanins and other phytochemical constituents of $H$. sabdiraffa extract such as protocatechmic acid, petine, hibiscetine and sabdaretine which have the potential to increase serum antioxidant capacity and thereby protecting against Low Density Lipoprotein oxidation leading to the prevention of cardiovascular disorders such as athrosclerosis. ${ }^{[16]-[18]}$ reported that oxidation of lowdensity lipoprotein (LDL) induces accumulation of macrophage in the artery wall and rupture of the plaque deposits oxidized cholesterol into the artery wall, leading to atherosclerosis and finally cardiovascular diseases.

However, our results also showed a significant increase in high density lipoprotein serum concentration in the test groups when compared to the control group $(\mathrm{P}<0.001)$ except in the comparison between group B and group A (control) where there was no significant difference $(\mathrm{P}<$ 0.1158) (table $2-5$ ). This result also agrees with the study of ${ }^{[19],[20]}$ and reports of ${ }^{[19]}$ reported that $H$. sabdariffa aqueous extract inhibits the development of atherosclerosis in cholesterol fed rabbits by lowering plasma lipids levels. The obtained result could be as a result of antioxidant activity of anthocyanins that prevents the oxidation of LDL which in strongly linked to atherosclerosis while promoting the activities and oxidation of HDL which play vital role in the prevention of deposition of lipid particles in the artery. Our result also agrees with the reports of $\mathrm{He}$ and Giusti, 2010; that anthocyanins are powerful antioxidants in vitro that prevents oxidation of lipids thereby lowering their concentration in the plasma. In addition, the results obtained also agrees with the reports of [16][18] that antioxidant activities effectively quench reactive oxygen species as well as free radicals, peroxides and singlet oxygen and ultimately involved in the prevention of cholesterol and LDL oxidation. They effectively quench free radicals and terminate the chain reaction that is responsible for the oxidative damage. Dietary antioxidants, including anthocyanins, have the potential to increase serum antioxidant capacity and thereby protect against LDL oxidation and prevent cardiovascular diseases.

\section{Conclusion}

This research would not be seen as conclusive but have provided a pointer on the possible hypolipidaemic effects of Hibiscus sabdariffa extract. However, it is advised that further research should be carried out using larger number of the experimental animals to determine the effect of long-term administration of $H$. sabdariffa extract on the degree of hypolipidaemia considering the trend of results obtained in this study.

\section{References}

1. Mohammed, R. Fernadezi, J. Pineda, M. and Aquilar, M. Rosella (Hibiscus sabdariffa) seed oil is a rich source of gamma tocopherol. Journal of Food Sciences, 2007, $72,207-211$.

2. Abdallah, M. A, Suliman, A. O., Eldeen, S. Idriss, A. A. and Abdualrahman, M. A. Y. A comparative study on red and white product. Pakistan Journal of Nutrition,2011, 10(7), 680-683.

3. Mohammed, B. B., Sulaiman, A.A. and Dahab, A. A. Roselle (Hibiscus sabdariffa L.) in Sudan, Cultivated and their uses. Bulletin of environment, pharmacology and life science,2012, 1, 6, 48 - 54.

4. Glew, R. H. Nutritional and chemical composition of 13 wild plant foods of Nigeria. Journal of Food Composition and Analysis, 2000, 13, 83 - 92.

5. Ahmed, S. E. and El-Nam, A. M. Effect of bleeding frequencies on growth and yield of two roselle (Hibiscus sabdariffa) varieties 
under rain fed. Australian Journal of Basic and Applied Sciences, 2010, 4(9), 510 - 512.

6. Da-Costa-Rocha, I., Bounnlaender, B., Sievers, H., Pischal, I. and Heinrich, M. Hibiscus sabdariffa L. - A phytochemical and pharmacological review. Food chemistry, 2014, 165, 424-443.

7. Gendy, A. S. H., Said-Al Ahl, H. A. H. and Mahmoud, A. A. Growth, Productivity and chemical constituents of Roselle (Hibiscus sabdariffa L.) plant as influenced by cattle manure and Biofertilizer treatment, Australian Journal of Basic and Applied Sciences, 2012, 6 (5), 1-12

8. Prior, R. L. and Cao, G. Antioxidant phytochemical in fruit and vegetables. Diet and health implications. Hortsciences, 2000, 35: $588-592$.

9. Murray, R. K., Granner, D. K., Mayes, P. A. and Podwell, V. W. Harper's Biochemistry, $25^{\text {th }}$ edition, McGraw Hill,2000, Pp. $268-$ 274.

10. Tsai, P.Mclntosh, J., Pearce, P., Camden, B. and Jordan, B. R. Anthocyanin and antioxidant capacity in roselle (Hibiscus sabdariffa) extract. Food Research International,2002, 35, $351-356$.

11. Levine, G. N., Keaney, J. F. and Vita, J. A. Cholesterol reduction in cardiovascular disease. New England Medical Journal, 2005, 5(23), 215 - 521.

12. Allen, R. G. and Tresini, M. Oxidative stress and gene regulation. Free Radical. Biology and Med.,2000, 28, 463 - 499.

13. Rao-pu. Nutrient composition and biological evaluation of mesta ((Hibiscus sabdariffa) Plant Food for Human Nutrition, 2006, 47(1), 27 - 34.

14. Omoniyi, J. O., Adegunloye, B. J., Owolabi, O. A., Ajagbonna, O. P., Sofola, O. A. and Coker, H. A. Mechanism of the blood pressure lowering effect of the calyx extract of Hibiscus sabdiraffa in rats. African Journal of Medicine and Medical Sciences, 1996, 25, 235 - 238
15. Tounkara, F., Amadou, S., Le, G. and Shi, Y. Effect of boiling on the physicochemical propertis of Roselle seeds (Hibiscus sabdariffa L.) cultivated in Mali. African journal of Biotechnology,2011, 10(79), 1810 $-18166$.

16. Aviram, M. Review of human studies on oxidative damage and antioxidant protection related to cardiovascular diseases. Free Radical Research,2000, 33, S85 - 97.

17. Sies, H., Stahl, W., Sevanian, A. Nutritional, dietary and postprandial oxidative stress. Journal of Nutrition,2005, 135(5), 959 972.

18. Sahu, S. C. Dual role of organosulfur compounds in foods. J. Environ. Sc. health C. Environ. Carcinog. Ecotoxicological Review, 2002, 20(1), $61-76$

19. Chen, C. C., Wang, S. F. and Chiang, H. C. Hibiscus sabdariffa extract inhibits the development of atherosclerosis in cholesterol fed rabbits. Journal of Food and Agriculture, 2002, 88(1), 154 - 158.

20. Hainida, E., Amin, I., Normah, H and ModbEsa, N. and Kekiah A. Effect of defatted dried rselle (Hibiscus sabdariffa L.) seeds powder on lipid profile of hypercholesterolaemic rats. Journal of the Science of Food and Agricultural,2008, 88, 1043 1050

21. He, J. and Giusti, M. M. Anthocyanins: Natural colourants with health-promoting properties. Annual Review of Food Science and Technology,2010, 1, $163-187$ 